\title{
Prevention of coprophagy in the rat. A new method
}

\author{
By B. K. ARMSTRONG AND A. SOFTLY \\ Department of Biochemistry and the Animal House, Royal Perth Hospital, \\ Perth, Western Australia
}

(Received 30 December I965-Accepted 25 April I966)

\begin{abstract}
I. Coprophagy in rats was prevented by the use of a leather jacket and large-mesh, screen floor cages. 2. This caused considerable depression of growth of prevented rats compared with non-prevented rats on the same dict.
\end{abstract}

Coprophagy may be a major variable in nutritional studies with the rat, particularly where they relate to vitamins synthesized by the intestinal bacteria (Elvehjem, 1948; Mickelsen, I956; Morgan, Gregory, Kon \& Porter, I964). Attempts to limit coprophagy were first made using screen-floor cages (Steenbock, Sell \& Nelson, 1923). It was later realized that this was not adequate, since the rat will take faeces direct from the anus (Roscoe, 1928). Attempts to prevent this were made by limiting body movements (Geyer, Geyer, Derse, Zinkin, Elvehjem \& Hart, 1947) and later by the use of faecal collection cups (Barnes, Fiala, McGehee \& Brown, 1957). The latter method is time-consuming and not always effective (Barnes $\&$ Fiala, 195 86 ) but has replaced the former since special cages are not required and the animal is less restricted.

To eliminate the necessity for continual emptying and replacement of faecal cups, we have used a jacket to prevent the rat from reaching its anus, without requiring special cages or excessive restriction of movement.

Growth studies of rats in whom coprophagy was prevented or permitted are described.

\section{EXPERIMENTAL}

Both male and female Wistar rats, weighing from 70 to roo g, were used. They were dipped in miticide several days before fitting jackets.

The jacket was cut out from soft purse leather to the pattern shown in Fig. I. Holes were punched along the edges for lacing and in the sides for ventilation.

The rats were quietened with Nembutal, the legs placed through the appropriate holes (Pl. I) and lacing was begun from the head. The laces were adjusted to give a firm, but not tight, fit and the string was tied at the tail in a knotted bow, to allow length for adjustment as the animal grew. The collar was stapled across $A A$ (Fig. r), allowing the thickness of a small pencil between it and the neck, and the hind-leg harness was stapled across $B B$ and $C C$, allowing freedom of movement of the legs. The 'vee' shaped tail cleft was then trimmed to clear the penis or vagina.

After fitting, the rats were returned to individual cages with $\frac{1}{2}$ in mesh screen floors. After they had settled down, final adjustments to the jackets were made with fine scissors. 
The growth of five rats in whom coprophagy was prevented, fitted with jackets when 6 weeks old, was compared with that of five rats of the same age in whom it was permitted, housed under similar conditions. Each rat received $10 \mathrm{~g} /$ day of a prepared diet (Table $\mathrm{r}$ ) and was weighed at regular intervals for a period of 6 weeks.

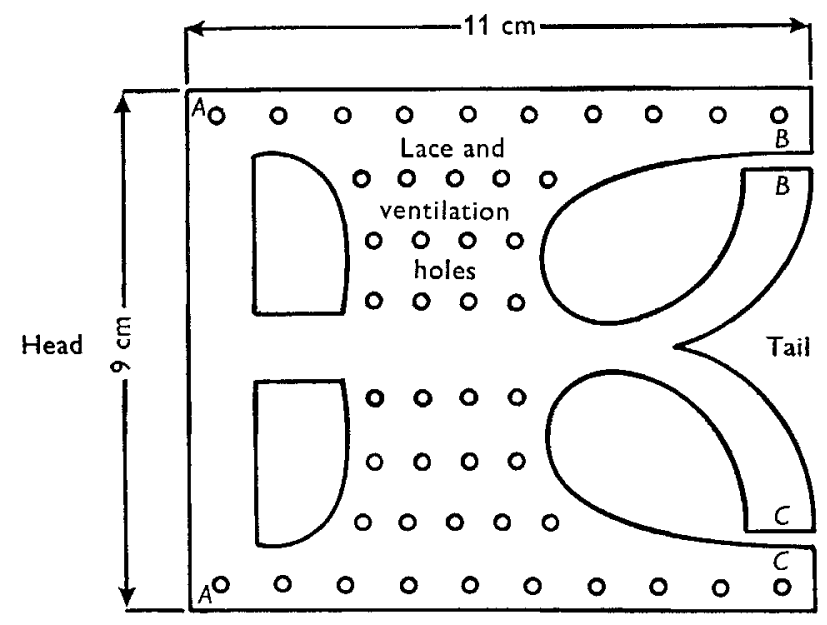

Fig. I. Outline pattern of jacket used to prevent coprophagy in the rat.

\section{Table I. Diet for growth studies with rats in whom coprophagy} was prevented or permitted

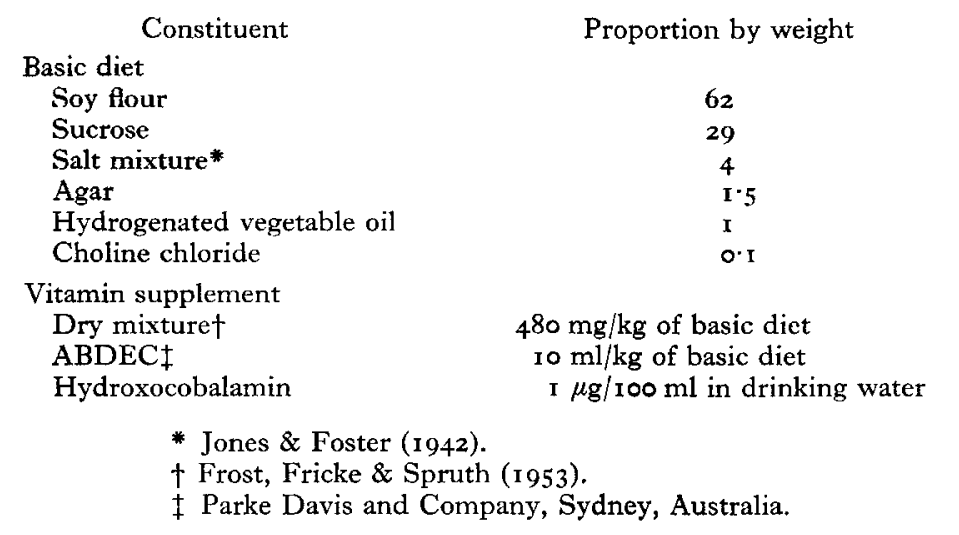

RESULTS

The rats varied in their response to the jacket but, in general, spent about $12 \mathrm{~h}$ struggling to escape-about 10\% succeeded. Within $24 \mathrm{~h}$ most of the animals were accustomed to it and resumed normal activities. Towards the end of the 6-week period some of the rats developed a 'spectacled eye' condition and some showed a marked tendency to lick the walls of their cages and the hands of their attendants.

Mean growth was significantly depressed, over 6 weeks, in rats in whom copro- 
phagy was prevented $\left(29^{\circ} 4 \pm 2.9 \mathrm{~g}\right)$ as compared with rats in whom it was not prevented $(76.9 \pm 5.5 \mathrm{~g})$ (Fig. 2). Adjustments to the lacing, and position of the staples were sufficient to allow for this growth.

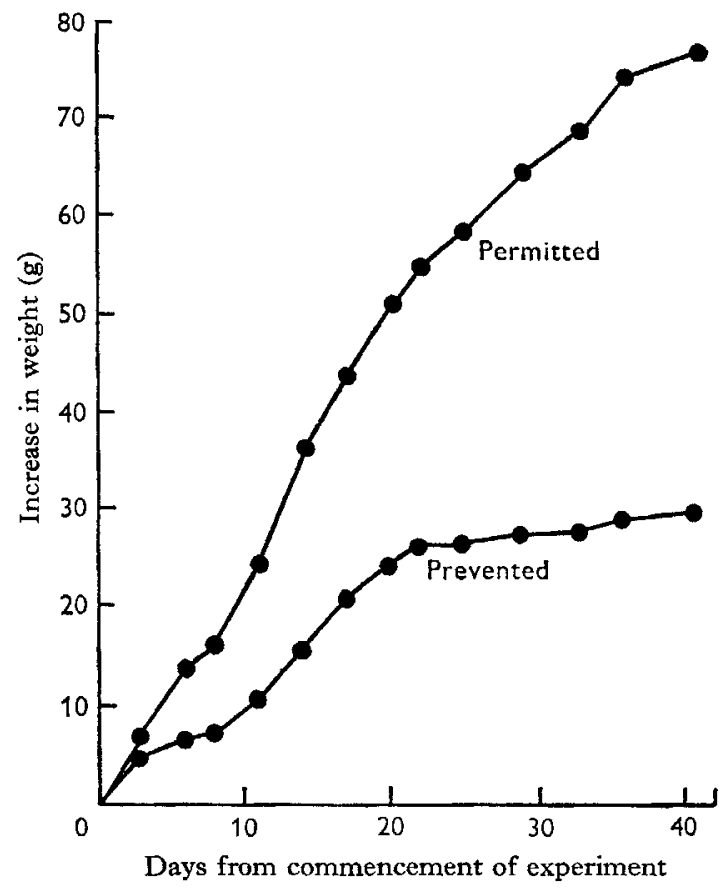

Fig. 2. Increase in mean weights over 6 wecks of rats in whom coprophagy was permitted or prevented on the same diet.

\section{DISCUSSION}

The construction of the jacket and the use of screen floors combine the requirements for prevention of access to faeces before, and after, defaecation. This method limits access to epidermal residues, but not faecal and urinary residues adhering to the screen floor. In these respects it is similar to the circular cage described by Geyer et al. (1947). It is thus not generally as effective as the faecal cup method, but occasional failure does not occur and less time is required in tending the animals.

The 'spectacled eye' condition and the licking tendency were similar to those observed by Geyer et al. (1947). The eye condition was probably not due to biotin deficiency since biotin was included in the vitamin supplement (Table I).

The growth of rats in the jackets was depressed (Fig. 2) to a greater extent than that described for rats with faecal cups (Barnes $\&$ Fiala, I95 $8 a$ ). This was probably due to the greater restriction due to the jacket. It was not due to a smaller intake of food by the prevented rats, as compared with the controls, since the amount of diet given was fully consumed by all rats.

In general, this method of coprophagy prevention should be satisfactory for investigations when growth estimates are not required. It might also be used for nonnutritional investigations when restriction of the animal is desired. 
We wish to thank Dr D. H. Curnow for his advice and criticism. The work was supported by a grant from the National Health and Medical Research Council of Australia.

\section{REFERENCES}

Barnes, R. H. \& Fiala, G. (1958a). F. Nutr. 64, 553.

Barnes, R. H. \& Fiala, G. (1958b). F. Nutr. 65, 103.

Barnes, R. H., Fiala, G., McGehee, B. \& Brown, A. (1957). F. Nutr. 63, 489.

Elvehjem, C. A. (1948). Fedn Proc. Fedn Am. Socs exp. Biol. 7, 4 I0.

Frost, D. V., Fricke, H. H. \& Spruth, H. C. (1953). F. Nutr. 49, 107.

Geyer, R. P., Geyer, B. R., Derse, P. H., Zinkin, T., Elvehjem, C. A. \& Hart, E. B. (1947). F. Nutr. 33, 129.

Jones, J. H. \& Foster, C. (1942). F. Nutr. 24, 245.

Mickelsen, O. (1956). Vitams Horm. 14, I.

Morgan, T. B., Gregory, M. E., Kon, S. K. \& Porter, J. W. G. (1964). Br. F. Nutr. 18, 595-

Roscoe, M. H. (r 928). J. Hyg., Camb. 27, ro3.

Steenbock, H., Sell, M. T. \& Nelson, E. M. (i923). F. biol. Chem. 55, 399.

\section{EXPLANATION OF PLATE}

Pl. I. Rats wearing jackets for preventing coprophagy. 
British Yournal of Nutrition, Vol. 20, No. 3

Plate I

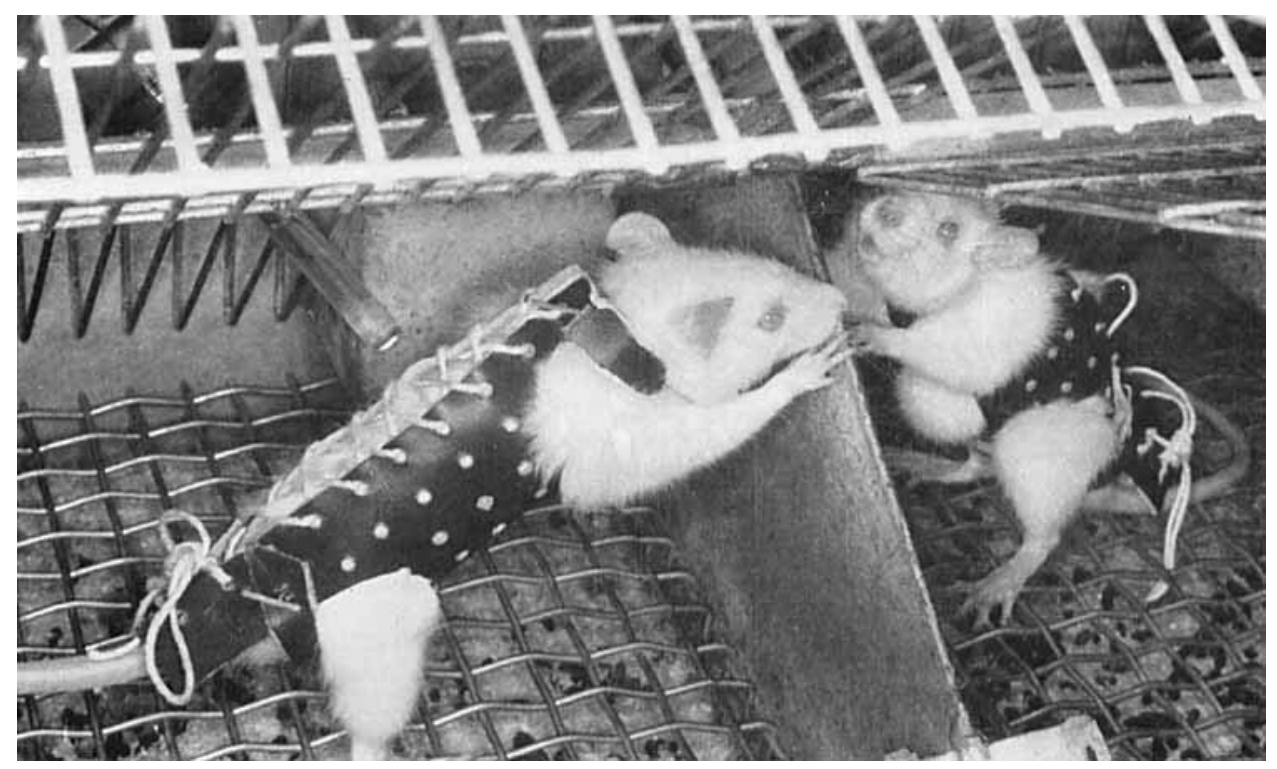

